\title{
Intracellular accumulation of Praziquantel in T lymphoblastoid cell lines, CEM (parental) and CEMvBL(P-gp-overexpressing)
}

Gabriel Kigen ${ }^{1,2^{*}}$ and Geoffrey Edwards ${ }^{2}$

\begin{abstract}
Background: Praziquantel (PZQ) is an antihelminthic drug whose P-glycoprotein (P-gp) substrate specificity has not been conclusively characterized. We investigated its specificity by comparing its in vitro intracellular accumulation in CEM (parental), and CEMvBL cells which over express P-gp, a drug efflux transporter. Saquinavir (SQV), a known substrate of efflux transporters was used as control.

Methods: A reversed phase liquid chromatography method was developed to simultaneously quantify PZQ and SQV in cell culture media involving involved a liquid - liquid extraction followed by ultra-high performance liquid chromatography using a Hypurity $C_{18}$ column and ultraviolet detection set at a wavelength of $215 \mathrm{~nm}$. The mobile phase consisted of ammonium formate, acetonitrile and methanol (57:38:5 v/v). Separation was facilitated via isocratic elution at a flow rate of $1.5 \mathrm{ml} / \mathrm{min}$, with clozapine (CLZ) as internal standard. This was validated over the concentration range of 1.6 to $25.6 \mu \mathrm{M}$ for all analytes. Intracellular accumulation of SQV in CEMvBL was significantly lower compared to that in CEM cells $(0.1 \pm 0.031$ versus $0.52 \pm 0.046, p=0.03$ $[p<0.05])$.
\end{abstract}

Results: Accumulation of PZQ in both cell lines cells were similar $(0.05 \pm 0.005$ versus $0.04 \pm 0.009, p=0.4)$ suggesting that it is not a substrate of P-gp in CEM cells. In presence tariquidar, a known inhibitor of P-gp, the intracellular accumulation of SQV in CEMvBL cells increased $(0.52 \pm 0.068$ versus $0.61 \pm 0.102, p=0.34$ in CEM cells and $0.09 \pm 0.015$ versus $0.56 \pm 0.089, p=0.029[p<0.05]$ in CEMvBL cells). PZQ did not significantly affect the accumulation of SQV in either CEM $(0.52 \pm 0.068$ versus $0.54 \pm 0.061, p=0.77)$, or in CEMvBL cells $(0.09 \pm 0.015$ versus $0.1 \pm 0.031, p=0.89)$ cells compared to tariquidar, implying that PZQ is not an inhibitor of P-gp in CEMvBL cells.

Conclusions: PZQ is neither a substrate nor an inhibitor of the efflux drug transporter P-gp in T-lymphoblastoid cells, CEM and CEMvBL. We also report a simple, accurate and precise method for simultaneous quantification of PZQ and SQV.

Keywords: Praziquantel, P-glycoprotein, Characterization, Pharmacokinetics

\footnotetext{
* Correspondence: kigengfk@gmail.com

${ }^{1}$ Department of Pharmacology and Toxicology, Moi University School of Medicine, P.O. Box 460630100 Eldoret, Kenya

${ }^{2}$ Department Molecular and Clinical Pharmacology, University of Liverpool, Liverpool L69 3GE, UK
} 


\section{Background}

Praziquantel (PZQ) is a broad spectrum antihelminthic drug used in the mass treatment of lymphatic filariasis and schistosomiasis which afflicts over 243 million people $[1,2]$. It is widely used because of its low cost and efficacy. It is also used in combination with albendazole for the treatment of neurocystercosis [3]. The three conditions constitute serious public health problems in the developing countries of Africa, Asia and Latin America [4, 5]. The same regions bear the burden of HIV/AIDS, especially sub-Saharan Africa. Praziquantel is therefore quite often co-administered with several other drugs including antiretroviral drugs [ARVs] [6-9]. The coadministration may give rise to drug-drug interactions that could influence the treatment outcomes, which in some instances may require dosage adjustments in order to prevent toxicity or resistance [10-12]. Despite its widespread use, there is currently limited information regarding PZQ's mechanisms of action at molecular level, and a lot more research is required in its pharmacokinetics in order to prevent resistance [13].

A possible mechanism for interactions between drugs results from the modulation of the efflux drug transporter, P-gp. P-gp functions to transport drugs from the intracellular to the extracellular domain, often against concentration gradients. The inhibition or potentiation of the transporter function will therefore have an impact on the cellular accumulations of the drug's efficacy $[14,15]$. Several drugs are substrates and/or inhibitors of efflux drug transporters and metabolic enzymes (especially CYP 3A4). Among the ARVs, protease inhibitors (PIs) including SQV are known to be substrates of P-gp, ABCC 1 and ABCC 2 [14, 16, 17]. With regards to drug transporter specificity, PZQ has not been conclusively characterized to date. In one study, the authors concluded that PZQ is an inhibitor of P-gp without being a substrate [18], whereas those in a related study indicated that PZQ did not show potential for interacting with cellular efflux pumps despite being a highly permeable substance $[19,20]$. PZQ has also been reported to inhibit the transport by SMDR2, a P-gp orthologue from $S$. mansoni [21], and P-gp has also been postulated to play a role in the resistance of PZQ [22-24].

The intracellular accumulation of drugs is controlled by several factors including ion trapping, lipophilicity and plasma protein binding, as well as influx and efflux transporters. With regards to PIs, drug transporters $\mathrm{P}$-gp, ABCC1, ABCC2 and BCRP play an important role in their accumulation [25, 26]. Being an efflux transporter, P-gp transports PIs from the intracellular to extracellular compartments, and the differences in their accumulation may be used to study their pharmacokinetics [15]. CEM cells treated with vinblastine (CEMvBL) overexpress P-gp [27], and the comparison of the in vitro accumulation of PIs in CEM parental and CEMvBL cells has been used to investigate the effects of active transport $[15,28]$. Previous studies in our laboratory have investigated the intracellular accumulation of SQV in T-lymphoblastoid cells, CEM parental and CEMvBL cells [25].

Our study had a double objective; to develop a suitable assay method for simultaneous quantification of both PZQ and SQV and to characterize PZQ with regards to substrate specificity of the transporter P-gp. In order to ascertain whether PZQ is a substrate of P-gp, its intracellular accumulation in CEM parental and CEMvBL cells which overexpress P-gp were compared to that of SQV, a known substrate of P-gp [15, 25, 28]. To determine whether it is an inhibitor, the accumulation of SQV in CEMvBL cells was compared to its accumulation in presence of $P Z Q$, and in presence of a known inhibitor, tariquidar (XR). A reversed phase liquid chromatography method was validated for simultaneous quantification of both PZQ and SQV in cell culture media and cell pellets.

\section{Methods}

Chemicals and reagents

SQV (Formula weight, 670.86) was donated by Roche Pharmaceuticals (Welwyn Garden City, UK). PZQ (cat. no. P4668, formula weight, 312.41); Clozapine [CLZ] (cat. no. C6305, Formula Weight, 326.82); Dulbecco's Modified Eagle's Medium, [DMEM] (cat. no. D6249, containing $4500 \mathrm{mg} / \mathrm{L}$ glucose, $4 \mathrm{mM}$ L-glutamine and $110 \mathrm{mg} / \mathrm{L}$ sodium pyruvate); Hanks Balanced Salt Solution [HBSS] (cat. no. H8264, modified with sodium bicarbonate, without phenol red, liquid, sterile-filtered, cell culture tested); Roswell Park Memorial Institute medium [RPMI] (cat. no. R8758)]; Foetal Bovine Medium, FBS (cat. F7524) and Trypsin-EDTA solution were purchased from Sigma Chemical Co. (Poole, UK). Acetonitrile $(\mathrm{ACN})$ and methanol $(\mathrm{MeOH})$ were purchased from VWR international (Leicestershire, UK); whereas diethyl ether was purchased from Fisher Scientific, (Leicestershire, UK). Tariquidar was kindly donated by Xenova Group plc (Berkshire, UK). All the other chemicals used were of analytical or HPLC grade. Deionised water used to prepare the solutions or mobile phase was purified in an Elga DV 25 pure lab option system (Elga, High Wycombe, Bucks, and UK). T-lymphoblastoid cell lines, CEM and CEMvBL cells were gifts from Dr. R. Davey (University of Queensland, Australia), and the cells were counted using a Nucleo Counter (ChemoMetec, Denmark) cell counter.

\section{Equipment and chromatographic conditions}

The high performance liquid chromatography (HPLC) consisted of a Dionex (Dionex Softron GmbH, Germany) 
HPLC system with a P 680 pump, an ASI-100 automated sample injector and a UVD 1704 detector. A $250 \mu \mathrm{l}$ injector with a $20 \mu \mathrm{l}$ loop was used. Reversedphase-liquid chromatography was carried out using a Hypurity $^{\text {Tix }} \quad C_{18}$ analytical column, $5 \mu \mathrm{m} \times 4.6 \mathrm{~mm}$ (Thermo Electron Corporation, Runcorn, UK 22105154630). A column guard (Thermo electron 60140-412) was used to protect the analytical column. The ultraviolet detector was set to monitor at $215 \mathrm{~nm}$ wavelength. The mobile phase for the analysis was composed of ammonium formate $20 \mathrm{mM}(\mathrm{pH}=4.2), \mathrm{ACN}$ and $\mathrm{MeOH}$ $(57: 38: 5 \mathrm{v} / \mathrm{v})$, and was prepared fresh for each assay. The separation was facilitated via isocratic elution at $1.5 \mathrm{ml} / \mathrm{min}$ flow rate and the run time was eight minutes for each separation. $20 \mu \mathrm{l}$ of the samples was injected for each run by means of an automated injector. The peak area ratios for the calibration curves and quantification were obtained and analyzed using Chromelon software (version 6.5).

\section{Preparation of stock solutions, calibrators, quality controls and internal standard Stock solutions}

Stock ammonium formate buffer was prepared by dissolving ammonium formate in deionised water to obtain a final concentration of $1 \mathrm{M}(63.06 \mathrm{mg} / \mathrm{ml})$. The $\mathrm{pH}$ was then adjusted by the addition of formic acid to $4.2 \mathrm{M}$, and stored at room temperature. This was stable for use for up to 6 months. Stock standard solutions of SQV, PZQ and the internal standard (IS), clozapine were prepared by dissolving the various solutions of the analyte in $\mathrm{MeOH}$ to obtain a final concentration of $1 \mathrm{mg} / \mathrm{ml}$. They were then capped, labeled and stored at $4{ }^{\circ} \mathrm{C}$ until use.

\section{Working solutions}

Working ammonium formate buffer (20 mM [1.26 mg/ml]) was prepared by diluting the stock buffer with deionised water, 1:50 (v/v). Working stock standard solutions $(100 \mu \mathrm{l}$ each) of PZQ and SQV were prepared by appropriate dilution in DMEM media over a concentration range of 1.6 to $25.6 \mu \mathrm{M}$ in duplicate (six concentration levels). Quality control (QC) samples $(100 \mu \mathrm{l})$ were prepared by diluting the stock solutions of the analytes to give $\mathrm{QC}$ concentrations of 6.4 (LQC), 12.8 (MQC) and 19.2 $\mu \mathrm{M}$ (HQC). Sufficient volume of the working internal standard $(5 \mu \mathrm{g} / \mathrm{ml})$ was prepared fresh for each assay in a serial dilution of the stock CLZ solution in $\mathrm{MeOH}$, first as 1 in 10 to give $10 \mu \mathrm{g} / \mathrm{ml}$ followed by 1 in 2 .

\section{Calibration curves}

Working stock standard solutions of PZQ and SQV were prepared by appropriate dilution in DMEM media. For the construction of the calibration curve, $100 \mu \mathrm{l}$ of the calibration standards were prepared by serial dilution of the stock SQV/PZQ solutions in DMEM (in duplicate), after thawing the samples resulting in seven concentration levels of $0,1.6,3.2,6.4,12.8,19.2$ and $25.6 \mu \mathrm{M}$ in $10 \mathrm{ml}$ labelled glass tubes (Table 1). Quality control samples $(100 \mu \mathrm{l})$ were prepared by thawing the stock QC samples and pipetting into separate $10 \mathrm{ml}$ labelled glass tubes (in duplicate) to give concentrations of 6.4 (LQC), 12.8 (MQC) and $19.2 \mu \mathrm{M}$ (HQC).

\section{Extraction procedure}

Before the analysis, $100 \mu \mathrm{l}$ of the calibration standards and QCs were pipetted in duplicate into $10 \mathrm{ml}$ labeled glass tubes. $20 \mu \mathrm{l}$ of $5 \mu \mathrm{g} / \mathrm{ml}$ of internal standard CLZ and $2 \mathrm{mls}$ of the extraction solvent diethyl ether were then added to each individual sample using a Finn repeater pipette. The tubes were then capped and tumbled for 30 min using a rotary mixer and then centrifuged for $5 \mathrm{~min}$ at $4000 \times g$. The aqueous phase was then frozen in a cryogenic bath and the solvent phases transferred to correspondently labelled $5 \mathrm{ml}$ clean tubes. This was followed by evaporation of the solvent to dryness using a centrifugal rotary evaporator (Jouan RC.10.10). The residues were reconstituted by the addition of $100 \mu \mathrm{l}$ mobile phase and all the tubes vortexed. $100 \mu \mathrm{l}$ of the samples were then aliquoted into autosampler vials, placed in corresponding numbered wells of the autosampler tray and securely capped. They were then centrifuged for $4 \mathrm{~min}$ at $4000 \times \mathrm{g}$, and injected into the HPLC column $(20 \mu \mathrm{l})$.

\section{Method validation}

The validation of the method was carried out as per the FDA guidelines.

Table 1 Concentrations of the standards and QCs

\begin{tabular}{lllll}
\hline Tube No. & Levels & SQV/PZQ Conc. $(\mu \mathrm{M})$ & Stock $(\mu \mathrm{l})$ & DMEM($\mu \mathrm{l})$ \\
\hline 1,2 & 1 & 0 & 0 & 100 \\
3,4 & 2 & 1.6 & 6.25 & 93.75 \\
5,6 & 3 & 3.2 & 12.5 & 87.5 \\
7,8 & 4 & 6.4 & 25 & 75 \\
9,10 & 5 & 12.8 & 50 & 50 \\
11,12 & 6 & 19.2 & 75 & 25 \\
13,14 & 7 & 25.6 & 100 & 0 \\
& Total & & $268.75(\mu l)$ & $431.25(\mu l)$ \\
& QCs & & & \\
15,16 & LQC & 6.4 & 100 & 0 \\
17,18 & MQC & 12.8 & 100 & 0 \\
19,20 & HQC & 19.2 & 100 & 0 \\
\hline
\end{tabular}




\section{Linearity}

In order to evaluate the linearity of the assay, ten sixpoint $(1.6,3.2,6.4,12.8,19.2$ and $25.6 \mu \mathrm{M})$ calibration curves were analyzed on separate days to determine the concentrations for each sample. The samples were extracted as described on section "Extraction procedure" and the standard curves were plotted as the peak area ratio (PAR) of the respective compound to the internal standard versus the concentration. The curves were obtained by the use of DMEM spiked with each of the six concentrations of both SQV and PZQ on the same run, and each point in the calibration curve run in duplicate. To assess linearity, the line of best fit was then determined by least squares regression.

\section{Limit of quantification}

The lowest limit of quantification (LLQ) for each drug was the minimal concentration that was within the range of the nominal concentration, with the acceptance criteria for each calculated standard concentration limited to not more than $20 \%$ deviation from the nominal value. Calibration curves were established with standard solutions for the concentration points of $1.6,3.2,6.4,12.8,19.2$ and $25.6 \mu \mathrm{M}$, all analyzed in quadruplicate.

\section{Limit of detection}

To determine the limit of detection (LLD), quadruplicate standard solutions for the concentration points of 1.6, $0.8,0.4,0.2,0.1$ and $0.05 \mu \mathrm{M}$ in were analyzed, and the peak areas of the respective drug concentration compared to that in DMEM (blank). The lowest concentration that produced a signal three or more times above the noise level of a blank preparation was designated as the limit of detection (LOD).

\section{Accuracy and precision}

Inter-day accuracy and precision ware evaluated by comparing ten replicate low, medium and high QC levels that were analyzed on different days. The intra-day accuracy and precision was determined by the analysis of the three concentrations of the QC samples in six replicates within the same day, evaluated in duplicate. The obtained results were expressed as relative standard deviations to the mean and the Coefficient of variation (CV) expressed as a percentage; that is $\mathrm{CV}=(\mathrm{SD} /$ Mean $) \times 100$. The accuracy and precision of the analytical method was based on the fact that the relative standard deviation of each concentration should be within $\pm 20 \%$ of the nominal concentration.

\section{Recovery}

The recovery or extraction efficiency of the analyte after the liquid-liquid extraction was determined by comparing the peak areas of six replicate samples of the QCs of each compound in extracted DMEM to those of non-processed standard solutions (standard solutions spiked in mobile phase). It was expressed as a percentage of the peak area of the extracted drug to that injected in MP.

\section{Specificity, selectivity and stability}

The separation from endogenous compounds was investigated by analyzing six different samples of DMEM. Short and long term stability was investigated by comparing the peak areas of six freshly prepared QC assay samples to those of the freeze-thawed samples, and it was expressed as a percentage.

\section{Drug accumulation experiments \\ Cell culture}

The parental cell line was CEM (T-lymphoblastoid cell line) was used as the parental cell line. CEMvBL cells that have increased expression of P-gp were selected under vinblastine [25]. The selection of drug resistant cells was carried out by using increasing concentrations of vinblastine up to $100 \mathrm{ng} / \mathrm{mL}$. CEM and CEMvbL Cells were cultured in $175 \mathrm{~cm}^{2}$ flasks containing DMEM supplemented with $15 \% \mathrm{FBS}$ at $37{ }^{\circ} \mathrm{C}$ in a humidified $5 \%$ $\mathrm{CO}_{2}$ gassed incubator, conditions which led to doubling after approximately every $24 \mathrm{~h}$. Aliquots $(100 \mu \mathrm{l})$ of CEM and CEMvBL Cells were then counted using Nucleo Counter (Chemometec, Denmark) and the appropriate volume containing 10 million cells was transferred into eight $20 \mathrm{ml}$ sterilin tubes, appropriately labelled for the following samples: CEM PZQ, VBL PZQ, CEM SQV and VBL SQV $[n=2]$.

\section{Intracellular accumulation of PZQ and SQV in CEM and CEMvBL cells}

The cell samples were centrifuged $(2000 \times g$ for 5 min at $4{ }^{\circ} \mathrm{C}$ ) and the supernatant fraction discarded. A total of $10 \mathrm{ml}$ of fresh DMEM media was added to the resulting pellets to give a concentration of 1 million cells $/ \mathrm{ml}$, and $100 \mu \mathrm{l}$ of $1 \mathrm{mg} / \mathrm{ml}$ of both PZQ and SQV to each respective tube resulting in a concentration of $10 \mu \mathrm{g} / \mathrm{ml}$. The cells were then incubated at $37{ }^{\circ} \mathrm{C}$ for $30 \mathrm{~min}$ in a shaking water bath. The resulting cell suspensions were then centrifuged $\left(2000 \times g\right.$ for $5 \mathrm{~min}$ at $\left.4^{\circ} \mathrm{C}\right) .100 \mu \mathrm{l}$ samples of the supernatant fraction were then removed, and the aliquots used to determine the extracellular (EXT) concentration. The excess supernatant fraction was then discarded and the resulting cell pellet washed three times in $10 \mathrm{ml} \mathrm{HBSS}$ and centrifuged $(2000 \times g$ for $5 \mathrm{~min}$ ). The resulting pellets were solubilized by reconstituting in $100 \mu \mathrm{l}$ of distilled water and used to determine intracellular (INT) concentrations as described 
in a method previously validated in our laboratory [29]. The experiment was carried out in quadruplicate. The samples were then assayed by HPLC, and the data expressed as cellular accumulation ratio (CAR), the ratio of the intracellular to the extracellular accumulation calculated by the formula, CAR $=($ INT/EXT $) \times 10$ [intracellular concentrations were calculated using the volume of a single CEM and CEMvBL cell to be 1 picolitre (pl)] [15, 30].

\section{Effect of $P Z Q$ and tariquidar on the intracellular} accumulation of SQV in CEM and CEMVBL cells

In the inhibition study, the cells (CEM and CEMvBL) spiked with a concentration of $10 \mu \mathrm{g} / \mathrm{ml}$ of SQV were incubated alone, and in the presence of $10 \mu \mathrm{g} / \mathrm{ml} \mathrm{PZQ;}$ and $1 \mu \mathrm{M}$ tariquidar (XR) respectively.

\section{Data analysis}

Statistical analysis was determined by Mann-Whitney $\mathrm{U}$ test. All results were presented as mean \pm S.D. with $95 \%$ confidence intervals for the difference between the means, where appropriate. Statistical analysis was performed by using the unpaired $t$-test and a two-tailed $P$ value of $<0.05$ was accepted as being significant.

\section{Results}

\section{Chromatography and detection}

The analysis of SQV and PZQ on the same mobile phase was highly dependent on the $\mathrm{pH}$ value of the mobile phase. Thus, the reverse-phase analysis was initially performed with various mixtures of ammonium formate,
$\mathrm{ACN}$ and $\mathrm{MeOH}$. The composition of the final mobile phase was $57 \%$ ammonium formate, $38 \% \mathrm{ACN}$ and $5 \%$ $\mathrm{MeOH}$. These conditions yielded satisfactory and reproducible retention times of both PZQ and SQV. CLZ was found to be the most suitable internal standard. A sample chromatogram of SQV, PZQ and CLZ is represented in Fig. 1. The retention time for SQV was $5.1 \mathrm{~min}$, whereas PZQ had $6.2 \mathrm{~min}$ and CLZ $2.2 \mathrm{~min}$, with the total run time being $8 \mathrm{~min}$. Detection at $215 \mathrm{~nm}$ provided adequate sensitivity.

\section{Linearity, limit of quantification and limit of detection}

The lower limit of quantification for both SQV and PZQ on the same run was $1.6 \mu \mathrm{M}$ whereas the upper limit of quantification was $25.6 \mu \mathrm{M}$. The concentration-response relationship for both SQV and PZQ standards was found to be linear in the concentration range of $1.6-25.6 \mu \mathrm{M}$ $(r=0.99773$ for PZQ and $r=0.9962$ for SQV) (Fig. 2). This linear relationship was demonstrated by a coefficient of variation obtained from the daily standard curves used for the analysis of unknown samples. The lowest limit of quantification (LLQ) was $1.6 \mu \mathrm{M}$, while the LLD was $0.1 \mu \mathrm{M}$ for both drugs.

\section{Accuracy and precision}

The mean inter-day precision was within the range for both drugs with average CVs of between 3.28 and $5.89 \%$ for PZQ, and 3.67 and 9.32 for SQV (Table 2). Similarly, the intra-day assay values were between 0.97 to 2.13 for PZQ and 0.86 to 2.15 for SQV (Table 2).

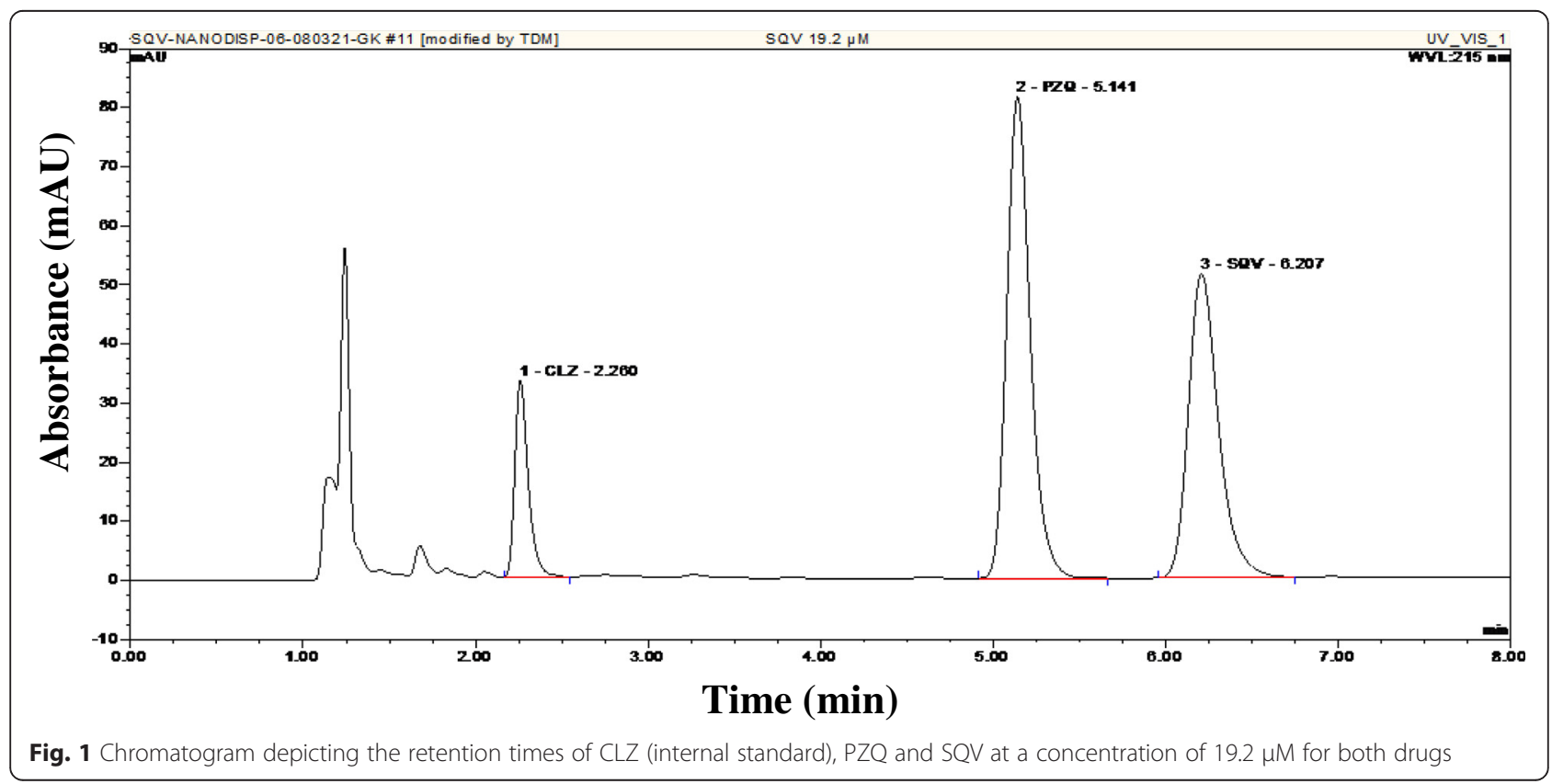




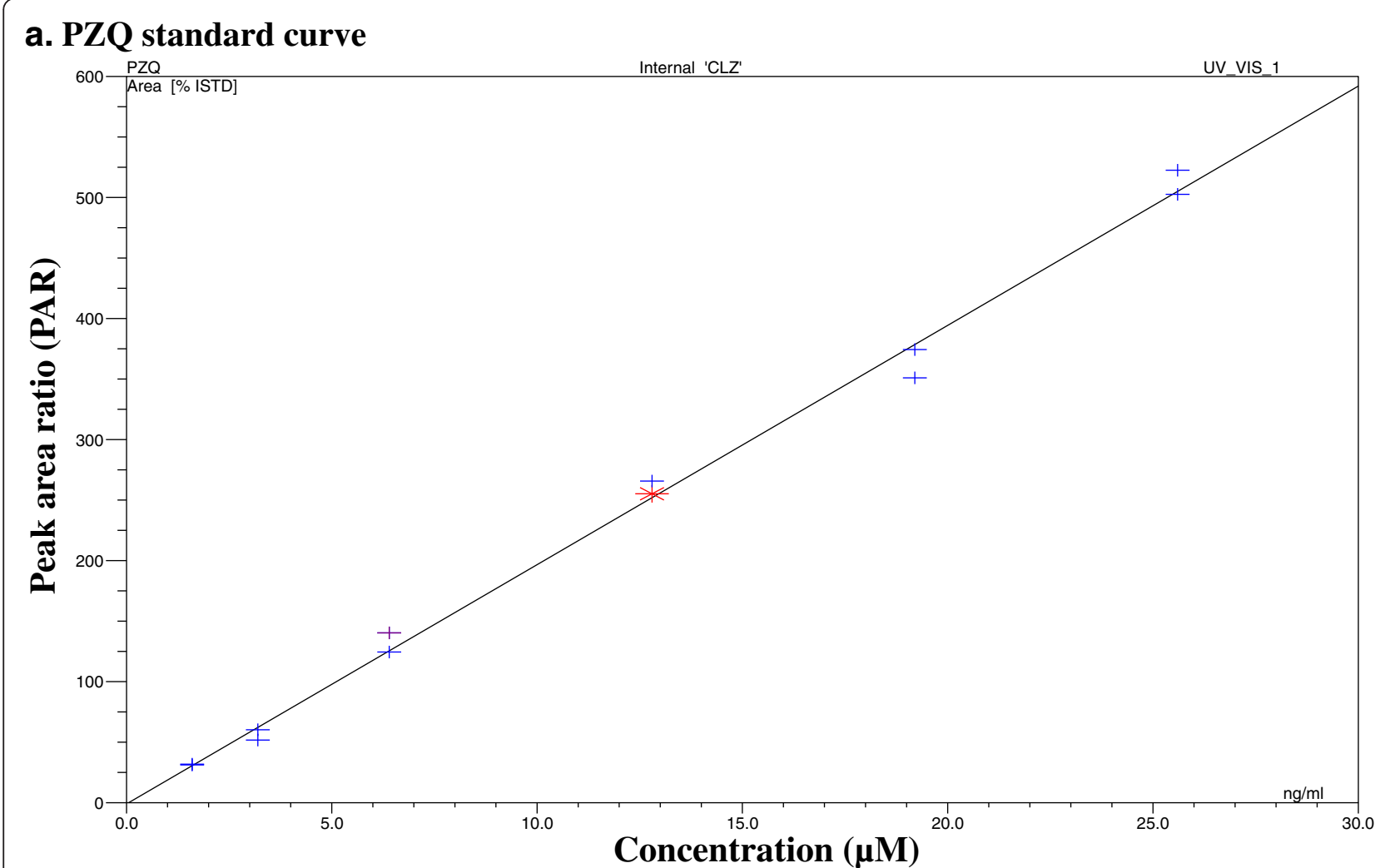

\section{b. SQV standard curve}

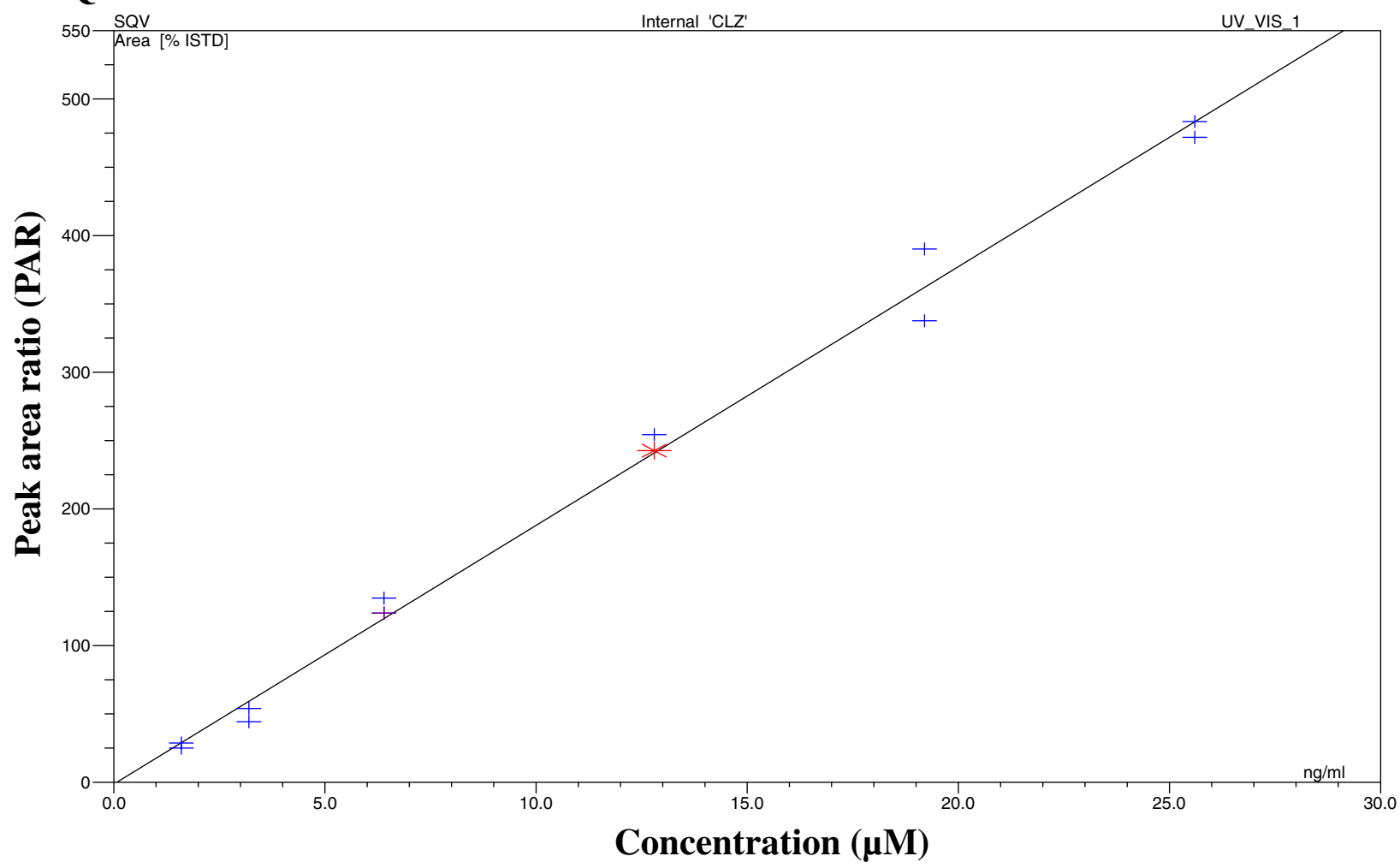

Fig. 2 Plots of the calibration curves showing the concentration response relationships of $\mathbf{a}(\mathrm{PZQ})$ and $\mathbf{b}(\mathrm{SQV})$ on the same run 
Table 2 Inter-day/intra-day precision, percentage recovery and stability

\begin{tabular}{|c|c|c|c|c|c|c|c|c|}
\hline \multirow[t]{2}{*}{ Drug } & \multicolumn{2}{|c|}{ Inter-day precision } & \multicolumn{2}{|c|}{ Intra-day precision } & \multicolumn{2}{|c|}{ Percentage recovery (\%) } & \multicolumn{2}{|l|}{ Stability } \\
\hline & Mean & CV (\%) & Mean & CV (\%) & Mean & CV (\%) & Mean & CV (\%) \\
\hline \multicolumn{9}{|l|}{ PZQ } \\
\hline LQC & $6.29( \pm 0.37)$ & 5.89 & $6.71( \pm 0.03)$ & 3.89 & $106( \pm 14)$ & 13.83 & $105( \pm 4)$ & 3 \\
\hline MQC & $12.78( \pm 0.58)$ & 4.06 & $11.67( \pm 0.14)$ & 4.06 & $115( \pm 6)$ & 5.59 & $113( \pm 6)$ & 5 \\
\hline HQC & $19.38( \pm 0.64)$ & 3.03 & $18.92( \pm 0.84)$ & 4.54 & $115( \pm 3)$ & 3.03 & $109( \pm 3)$ & 3 \\
\hline \multicolumn{9}{|l|}{ SQV } \\
\hline LQC & $6.23( \pm 0.58)$ & 9.32 & $6.68( \pm 0.58)$ & 4.32 & $95( \pm 6)$ & 7.28 & $91( \pm 5)$ & 6 \\
\hline MQC & $12.8( \pm 0.93)$ & 7.24 & $12.61( \pm 0.18)$ & 7.24 & $110( \pm 10)$ & 9.58 & $100( \pm 5)$ & 5 \\
\hline $\mathrm{HQC}$ & $18.94( \pm 0.69)$ & 3.67 & $19.63( \pm 0.91)$ & 3.69 & $101( \pm 4)$ & 4.46 & $87( \pm 2)$ & 2 \\
\hline
\end{tabular}

\section{Recovery}

The mean recovery for both drugs in DMEM was always greater than $92 \%$ for both drugs within the analyzed concentration range of $6.4 \mu \mathrm{M}$ (MQC) to $19.2 \mu \mathrm{M}$ (HQC) (Table 2).

\section{Specificity and selectivity}

The selectivity of the chromatographic separation was demonstrated by the absence of interfering endogenous peaks in DMEM (Fig. 3).

\section{Stability}

Freeze thawing DMEM samples containing SQV and PZQ did not appear to significantly affect the concentrations when compared to fresh samples (Table 2).

\section{Accumulation experiments}

The chromatograms illustrating the extracellular and intracellular accumulation of both SQV and PZQ in CEM and CEMvBL cells are depicted in Fig. 4. The accumulation of SQV was significantly lower in CEMvBL than CEM cells $(0.1 \pm 0.031$ versus $0.52 \pm 0.046, p=0.03[p<0.05])$, whereas similar accumulation of PZQ occurred in both cell lines $(0.05 \pm 0.005$ versus $0.04 \pm 0.009, p=0.4)$ [Table 3; Fig. 5].

PZQ did not significantly affect the accumulation of SQV in either CEM $(0.52 \pm 0.068$ versus $0.54 \pm 0.061$, $p=0.77)$, or in CEMvBL cells $(0.09 \pm 0.015$ versus 0.1 $\pm 0.031, p=0.89)$ cells as compared to tariquidar; $0.52 \pm 0.068$ versus $0.61 \pm 0.102, p=0.34$ in CEM cells and $0.09 \pm 0.015$ versus $0.56 \pm 0.089, p=0.029[p<$ 0.05] in CEMvBL cells (Table 4; Fig. 6).

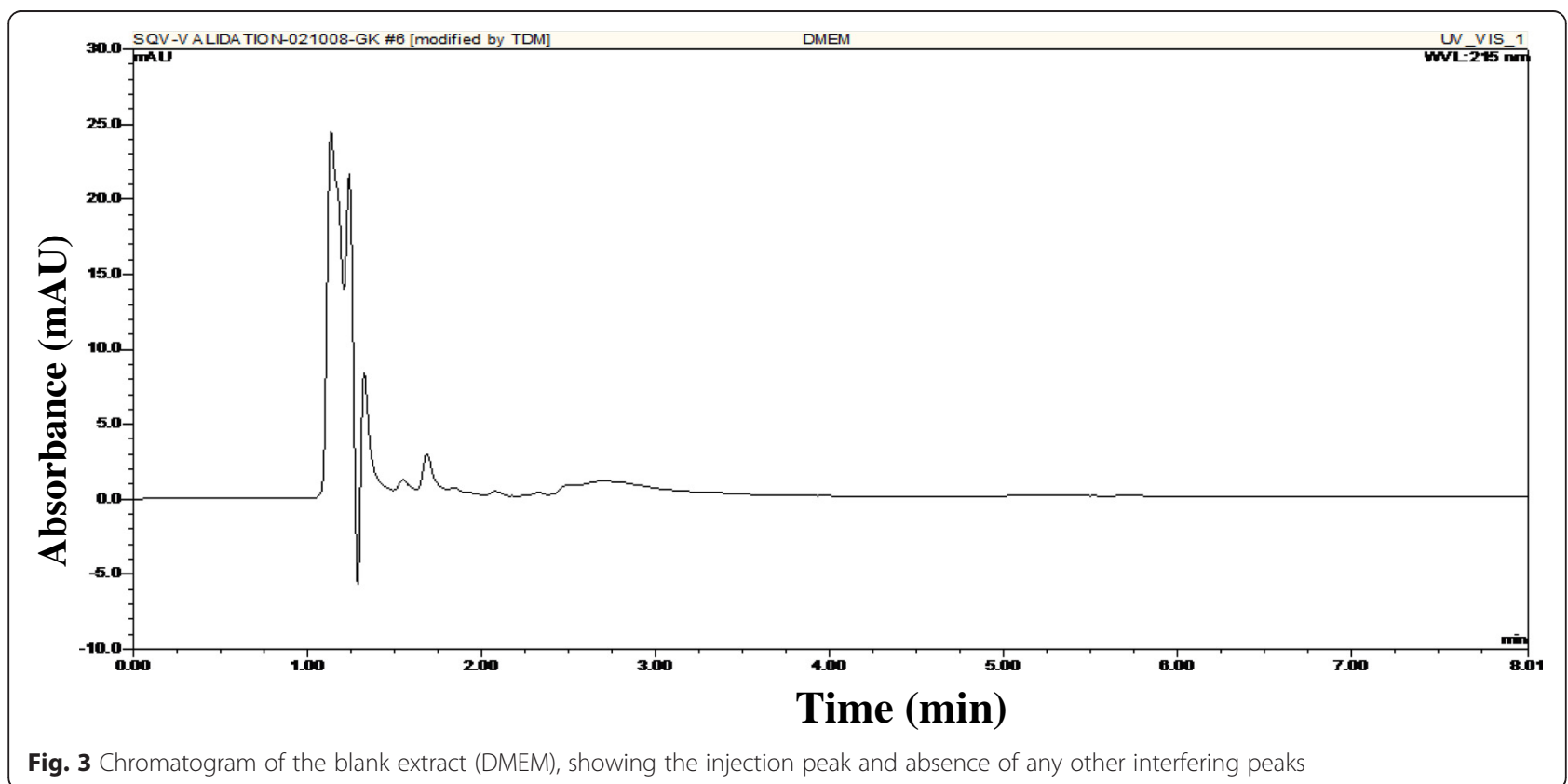




\section{a. CEMSQV/PZQ extracellular}

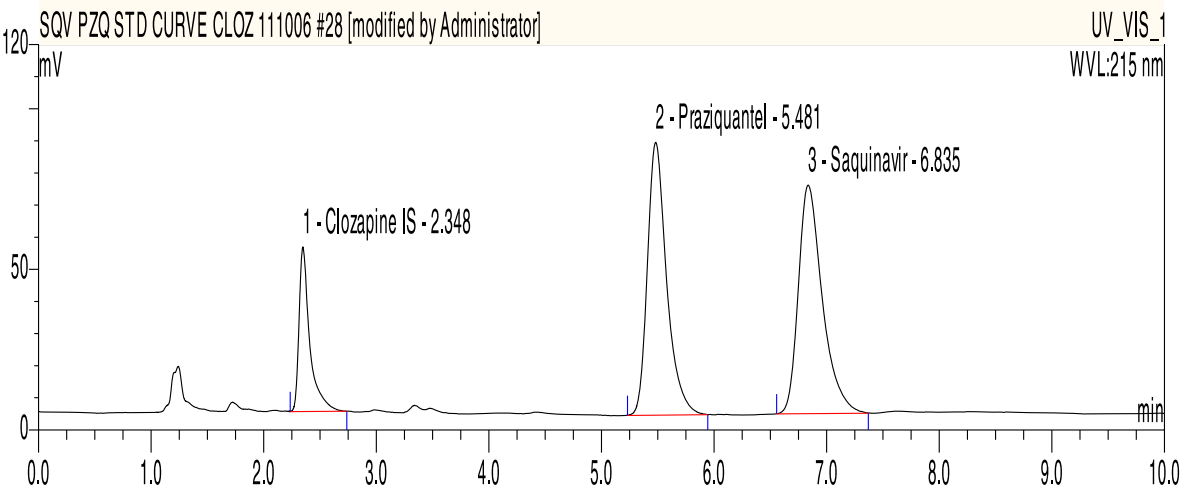

b. VBLSQV/PZQ extracellular

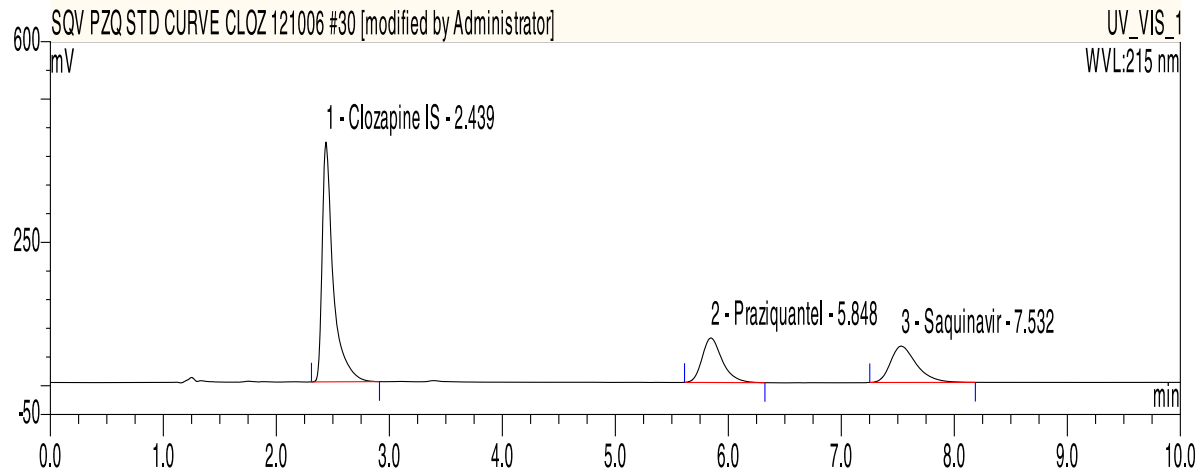

\section{c. VBL SQV/PZQ intracellular}

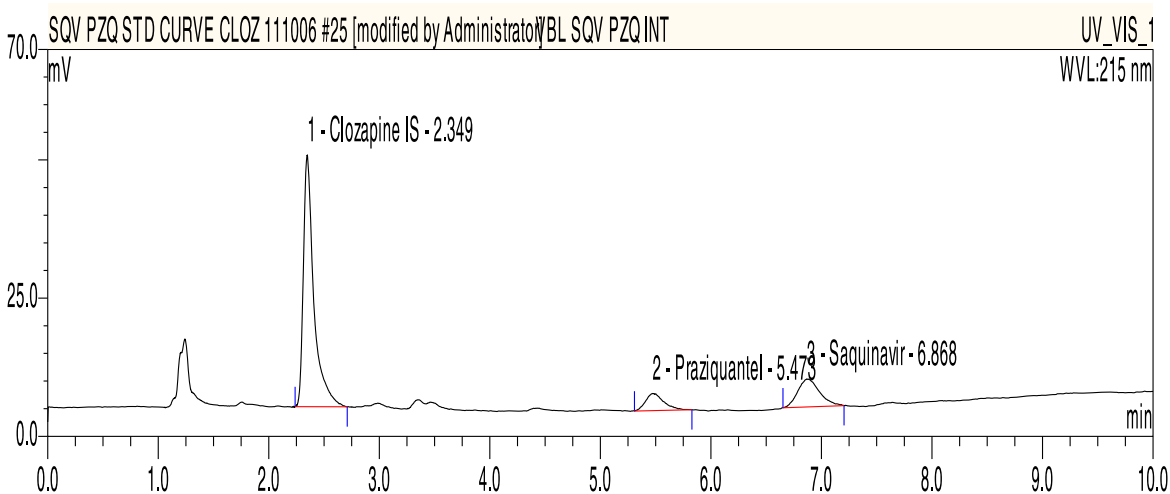

Fig. 4 Chromatograms showing the extracellular accumulation of SQV/PZQ in CEM parental (a), and CEMvBL cells (b); and intracellular accumulation in CEMvBL cells $(\mathbf{c})$

\section{Discussion}

The purpose of this research was to characterize the P-gp substrate specificity of $\mathrm{PZQ}$, a widely used drug as an attempt to understand its pharmacokinetics. This was done by investigating its intracellular accumulation in $\mathrm{T}$ lymphoblastoid cells, CEM parental and CEMvBL cells which overexpress P-gp. A reversed phase HPLC method was developed for quantification.

P-gp plays an important role in the movement of many drugs across biological membranes, especially those administered through the oral route. It functions as a transmembrane efflux pump; pumping its substrates outside the cells, hence affecting its tissue concentrations and resultant pharmacological effects, including drugs interactions and resistance [31-34]. The inhibition or potentiation of the transporter function will therefore have an impact on the cellular accumulations of the drugs and efficacy, an example being the reported reduction in plasma concentrations of PIs [35-38]. In addition, the efflux protein is present in several important body 
Table 3 Cellular accumulation ratio (CAR) values for the substrate studies

\begin{tabular}{lllll}
\hline Sample & CEM SQV & VBL SQV & CEM PZQ & VBL PZQ \\
\hline 1 & 0.54 & 0.12 & 0.03 & 0.06 \\
2 & 0.52 & 0.14 & 0.05 & 0.05 \\
3 & 0.45 & 0.07 & 0.05 & 0.05 \\
4 & 0.55 & 0.08 & 0.04 & 0.05 \\
Mean & 0.52 & 0.10 & 0.04 & 0.05 \\
STDEV & 0.046 & 0.031 & 0.009 & 0.005 \\
$p$ value & $p=0.03$ & & $p=0.4$ & \\
\hline
\end{tabular}

tissues including the intestines, liver, kidney, brain and placenta where it has role in modulating its substrate drugs $[39,40]$. P-gp along with CYP 450 group of enzymes are therefore important determinants of the pharmacokinetics of several drugs, since many are its substrates. The determination of the substrate specificity of a drug to either efflux proteins and/or metabolizing enzymes is therefore important in the understanding of its pharmacokinetics [41-44]. Indeed, the substrate specificity of several drugs to Pgp has now been characterized [32, 45].

Despite its widespread use, PZQ's substrate specificity to P-gp has not been conclusively characterized, since authors from previous studies arrived at conflicting conclusions. Researchers from two groups concluded that it was not a substrate $[19,20]$, whereas another team concluded that it was an inhibitor without being a substrate [18]. However, it is noteworthy that Caco-2 cell lines used by the second group express several drug transporters (influx as well as efflux) including metabolic enzymes. An interplay of several factors is therefore possible, and careful interpretation of the results may be necessary [46-49].

In order to determine the P-gp substrate specificity of PZQ, we developed an analytical method that compared intracellular accumulations of the drug in $\mathrm{T}$ lymphoblastoid cells, CEM (control) and CEMvBL which overexpress P-gp, alone and in presence of SQV, a known substrate of P-gp. Several methods have been developed

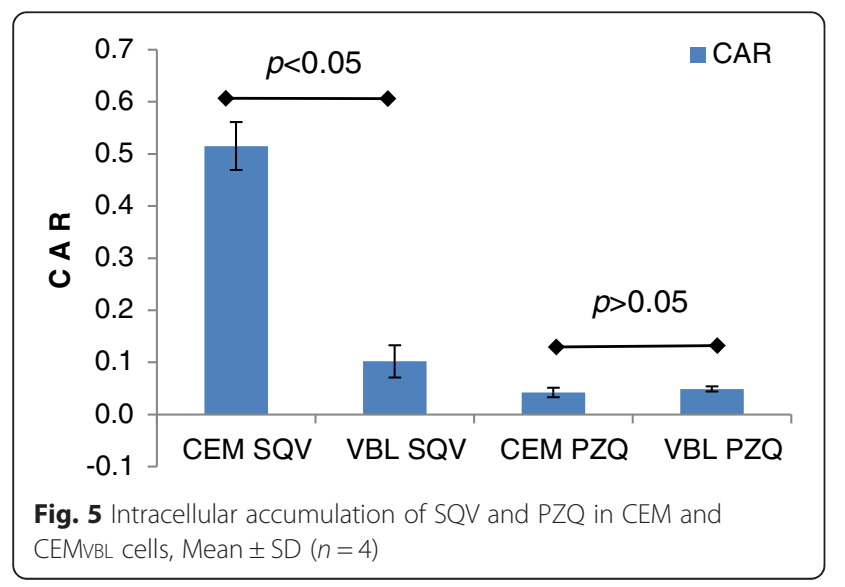

Table 4 Cellular accumulation ratio values for inhibition studies

\begin{tabular}{lllllll}
\hline Sample & CEM SQV & $\begin{array}{l}\text { CEMSQV } \\
\text { PZQ }\end{array}$ & $\begin{array}{l}\text { CEMSQV } \\
\text { XR }\end{array}$ & $\begin{array}{llll}\text { VBL SQV } \\
\text { VBL SQV } \\
\text { PZQ }\end{array}$ & $\begin{array}{l}\text { VBL SQV } \\
\text { XR }\end{array}$ \\
\hline 1 & 0.57 & 0.45 & 0.55 & 0.07 & 0.08 & 0.53 \\
2 & 0.50 & 0.57 & 0.51 & 0.10 & 0.07 & 0.50 \\
3 & 0.59 & 0.59 & 0.73 & 0.10 & 0.13 & 0.69 \\
4 & 0.44 & 0.53 & 0.66 & 0.11 & 0.13 & 0.52 \\
Mean & 0.52 & 0.54 & 0.61 & 0.09 & 0.10 & 0.56 \\
STDEV & 0.068 & 0.061 & 0.102 & 0.015 & 0.031 & 0.089 \\
$p$ value & & $p=0.77$ & $p=0.34$ & & $p=0.89$ & $p=0.03$ \\
\hline
\end{tabular}

to quantify PZQ levels, alone $[50,51]$ or in combination with other drugs [52-54]; but none so far for simultaneous determination of the drug and ARVs. We chose to use SQV, a PI as PZQ may be co-administered with PIs, since there is geographic overlap between the regions afflicted by both Schistosomiasis and HIV/AIDS [55]. The method was validated over a concentration range of 1.6 to $19.2 \mu \mathrm{M}$ for both drugs (50 to $600 \mathrm{ng} / \mathrm{ml}$ for PZQ and 107 to $1288 \mathrm{ng} / \mathrm{ml}$ for SQV); which is within the detectable range for both drugs in human plasma [56, 57].

\section{Conclusion}

The results from our accumulation results indicate that PZQ is neither a substrate nor an inhibitor of P-gp in T lymphoblastoid cells, CEM and CEMvBL. We also report a simple, accurate and precise method for simultaneous quantification of PZQ and SQV. Several HPLC methods have been developed for the determination of PZQ alone $[50,51]$, or simultaneously with other antihelminthics $[58,59]$. However, to date there is none reported in the literature that has been developed for concurrent analysis of antiretroviral and antihelminthic drugs. We for the first time report a simple and accurate HPLC method for the simultaneous quantification of PZQ and SQV. This method may be used to investigate the pharmacokinetics of $\mathrm{PZQ}$, including the potential drug interactions between antihelminthic and antiretroviral drugs.

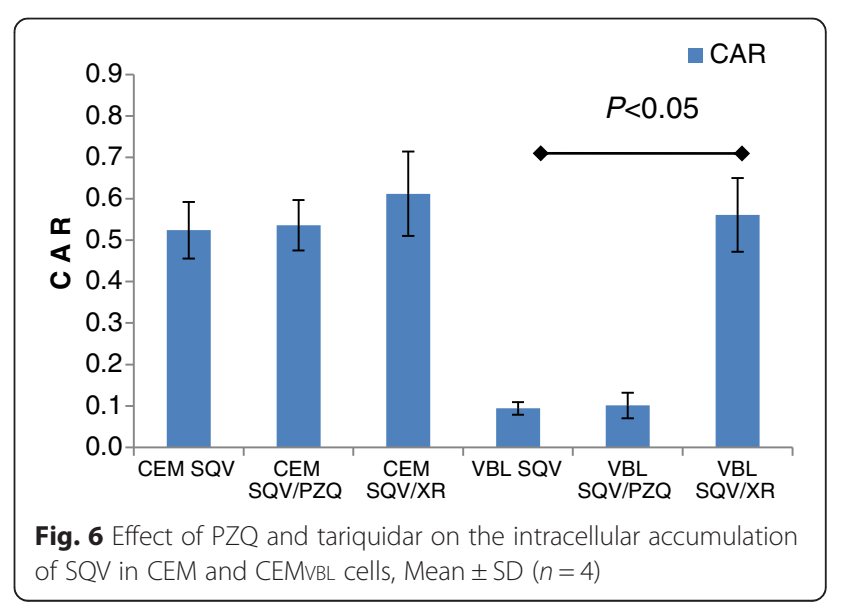




\section{Acknowledgements}

We wish to thank the staff at the Department of Molecular and Clinical Pharmacology, University of Liverpool for the support of the research project.

\section{Funding}

This work was supported by the Government of the Republic of Kenya which funded Gabriel Kigen's PhD study at the University of Liverpool.

\section{Availability of data and material}

Not applicable.

\section{Authors' contributions}

Conception and design: GK, GE. Acquisition of Data: GK. Analysis of data: GK, GE. Writing of the paper: GK, GE. All authors have read and approved of the final version of the manuscript.

\section{Competing interests}

The authors declare that they have no competing interests.

\section{Consent for publication}

Not applicable.

\section{Ethics approval and consent to participate}

Not applicable.

\section{Received: 20 November 2015 Accepted: 19 July 2016}

Published online: 14 August 2016

\section{References}

1. Steinmann P, Keiser J, Bos R, Tanner M, Utzinger J. Schistosomiasis and water resources development: systematic review, meta-analysis, and estimates of people at risk. Lancet Infect Dis. 2006;6:411-25.

2. WHO. Schistosomiasis: number of people treated worldwide in 2014. Wkly Epidemiol Rec. 2016;91:53-60.

3. Coyle CM, Tanowitz HB. Diagnosis and treatment of neurocysticercosis. Interdiscip Perspect Infect Dis. 2009;2009:180742.

4. Prichard RK, Basanez MG, Boatin BA, McCarthy JS, Garcia HH, Yang GJ, Sripa $B$, Lustigman S. A research agenda for helminth diseases of humans: intervention for control and elimination. PLoS Negl Trop Dis. 2012;6:e1549.

5. Steinmann P, Utzinger J, Du ZW, Zhou XN. Multiparasitism a neglected reality on global, regional and local scale. Adv Parasitol. 2010;73:21-50.

6. Hotez PJ, Molyneux DH, Fenwick A, Kumaresan J, Sachs SE, Sachs JD, Savioli L. Control of neglected tropical diseases. N Engl J Med. 2007;357:1018-27.

7. Mbabazi PS, Andan O, Fitzgerald DW, Chitsulo L, Engels D, Downs JA Examining the relationship between urogenital schistosomiasis and HIV infection. PLoS Negl Trop Dis. 2011;5:e1396.

8. Seden K, Khoo S, Back D, Prevatt N, Lamorde M, Byakika-Kibwika P, Mayito J, Ryan M, Merry C. Drug-drug interactions between antiretrovirals and drugs used in the management of neglected tropical diseases: important considerations in the WHO 2020 Roadmap and London Declaration on Neglected Tropical Diseases. AIDS. 2013;27:675-86

9. Kjetland EF, Ndhlovu PD, Gomo E, Mduluza T, Midzi N, Gwanzura L, Mason PR, Sandvik L, Friis $H$, Gundersen SG. Association between genital schistosomiasis and HIV in rural Zimbabwean women. AIDS. 2006:20:593-600.

10. Piscitelli SC, Gallicano KD. Interactions among drugs for HIV and opportunistic infections. N Engl J Med. 2001;344:984-96.

11. Pontali E. Interactions of antiretroviral drugs with anti-infectives and other antiretrovirals. Chemotherapy. 2007:53:26-9.

12. Young B. Review: mixing new cocktails: drug interactions in antiretroviral regimens. AIDS Patient Care STDS. 2005;19:286-97.

13. Doenhoff MJ, Hagan P, Cioli D, Southgate V, Pica-Mattoccia L, Botros S, Coles G, Tchuem Tchuenté LA, Mbaye A, Engels D. Praziquantel: its use in control of schistosomiasis in sub-Saharan Africa and current research needs. Parasitology. 2009;136:1825-35.

14. Kim RB, Fromm MF, Wandel C, Leake B, Wood AJ, Roden DM, Wilkinson GR. The drug transporter P-glycoprotein limits oral absorption and brain entry of HIV-1 protease inhibitors. J Clin Invest. 1998;101:289-94.

15. Jones K, Hoggard PG, Sales SD, Khoo S, Davey R, Back DJ. Differences in the intracellular accumulation of HIV protease inhibitors in vitro and the effect of active transport. AIDS. 2001;15:675-81.
16. Gimenez F, Fernandez C, Mabondzo A. Transport of HIV protease inhibitors through the blood-brain barrier and interactions with the efflux proteins, P-glycoprotein and multidrug resistance proteins. J Acquir Immune Defic Syndr. 2004;36:649-58.

17. Profit L, Eagling VA, Back DJ. Modulation of P-glycoprotein function in human lymphocytes and Caco-2 cell monolayers by HIV-1 protease inhibitors. AIDS. 1999;13:1623-7.

18. Hayeshi R, Masimirembwa C, Mukanganyama S, Ungell AL. The potential inhibitory effect of antiparasitic drugs and natural products on P-glycoprotein mediated efflux. Eur J Pharm Sci. 2006;29:70-81.

19. Gonzalez-Esquivel D, Rivera J, Castro N, Yepez-Mulia L, Jung Cook H. In vitro characterization of some biopharmaceutical properties of praziquantel. Int J Pharm. 2005:295:93-9.

20. Dupuy J, Alvinerie M, Menez C, Lespine A. Interaction of anthelmintic drugs with P-glycoprotein in recombinant LLC-PK1-mdr1a cells. Chem Biol Interact. 2010;186:280-6.

21. Kasinathan RS, Goronga T, Messerli SM, Webb TR, Greenberg RM. Modulation of a Schistosoma mansoni multidrug transporter by the antischistosomal drug praziquantel. FASEB J. 2010;24:128-35.

22. Messerli SM, Kasinathan RS, Morgan W, Spranger S, Greenberg RM. Schistosoma mansoni P-glycoprotein levels increase in response to praziquantel exposure and correlate with reduced praziquantel susceptibility. Mol Biochem Parasitol. 2009;167:54-9.

23. Kasinathan RS, Sharma LK, Cunningham C, Webb TR, Greenberg RM. Inhibition or knockdown of $A B C$ transporters enhances susceptibility of adult and juvenile schistosomes to praziquantel. PLoS Negl Trop Dis. 2014;8:e3265.

24. Pinto-Almeida A, Mendes T, Armada A, Belo S, Carrilho E, Viveiros M, Afonso A. The role of efflux pumps in Schistosoma mansoni praziquantel resistant phenotype. PLoS One. 2015;10:e0140147.

25. Janneh O, Owen A, Chandler B, Hartkoorn RC, Hart CA, Bray PG, Ward SA, Back DJ, Khoo SH. Modulation of the intracellular accumulation of saquinavir in peripheral blood mononuclear cells by inhibitors of MRP1, MRP2, P-gp and BCRP. AIDS. 2005;19:2097-102.

26. Hoggard $P G$, Owen A. The mechanisms that control intracellular penetration of the HIV protease inhibitors. J Antimicrob Chemother. 2003; 51:493-6.

27. Beck WT, Mueller TJ, Tanzer LR. Altered surface membrane glycoproteins in Vinca alkaloid-resistant human leukemic lymphoblasts. Cancer Res. 1979;39: 2070-6.

28. Khoo SH, Hoggard PG, Williams I, Meaden ER, Newton P, Wilkins EG, Smith A, Tjia JF, Lloyd J, Jones K, et al. Intracellular accumulation of human immunodeficiency virus protease inhibitors. Antimicrob Agents Chemother. 2002:46:3228-35.

29. Janneh O, Jones $\mathrm{E}$, Chandler B, Owen A, Khoo SH. Inhibition of P-glycoprotein and multidrug resistance-associated proteins modulates the intracellular concentration of lopinavir in cultured CD4 T cells and primary human lymphocytes. J Antimicrob Chemother. 2007;60:987-93.

30. Ford J, Boffito M, Wildfire A, Hill A, Back D, Khoo S, Nelson M, Moyle G, Gazzard B, Pozniak A. Intracellular and plasma pharmacokinetics of saquinavir-ritonavir, administered at 1,600/100 milligrams once daily in human immunodeficiency virus-infected patients. Antimicrob Agents Chemother. 2004;48:2388-93.

31. Ho RH, Kim RB. Transporters and drug therapy: implications for drug disposition and disease. Clin Pharmacol Ther. 2005;78:260-77.

32. Jovelet C, Benard J, Forestier F, Farinotti R, Bidart JM, Gil S. Inhibition of P-glycoprotein functionality by vandetanib may reverse cancer cell resistance to doxorubicin. Eur J Pharm Sci. 2012:46:484-91.

33. Fromm MF. Importance of P-glycoprotein at blood-tissue barriers. Trends Pharmacol Sci. 2004;25:423-9.

34. Finch A, Pillans P. P-glycoprotein and its role in drug-drug interactions. Aust Prescr. 2014;37:137-9.

35. Igel S, Drescher S, Murdter T, Hofmann U, Heinkele G, Tegude H, Glaeser H, Brenner SS, Somogyi AA, Omari T, et al. Increased absorption of digoxin from the human jejunum due to inhibition of intestinal transportermediated efflux. Clin Pharmacokinet. 2007;46:777-85

36. Zhou S, Wang L, Di Y, Xue C, Duan W, Li C, Li Y. Substrates and inhibitors of human multidrug resistance associated proteins and the implications in drug development. Curr Med Chem. 2008;15:1981.

37. Jones K, Bray P, Khoo S, Davey R, Meaden E, Ward S, Back D. P-Glycoprotein and transporter MRP1 reduce HIV protease inhibitor uptake in CD4 cells: potential for accelerated viral drug resistance? AIDS. 2001;15:1353. 
38. Agarwal S, Pal D, Mitra AK. Both P-gp and MRP2 mediate transport of Lopinavir, a protease inhibitor. Int J Pharm. 2007:339:139-147.

39. Thiebaut F, Tsuruo T, Hamada H, Gottesman MM, Pastan I, Willingham MC. Cellular localization of the multidrug-resistance gene product P-glycoprotein in normal human tissues. Proc Natl Acad Sci U S A. 1987:84:7735-8.

40. Fromm MF. P-glycoprotein: a defense mechanism limiting oral bioavailability and CNS accumulation of drugs. Int J Clin Pharmacol Ther. 2000;38:69-74

41. Lin JH, Yamazaki M. Role of P-glycoprotein in pharmacokinetics: clinical implications. Clin Pharmacokinet. 2003;42:59-98.

42. Konig J, Muller F, Fromm MF. Transporters and drug-drug interactions: important determinants of drug disposition and effects. Pharmacol Rev. 2013;65:944-66.

43. Darwich AS, Neuhoff S, Jamei M, Rostami-Hodjegan A. Interplay of metabolism and transport in determining oral drug absorption and gut wall metabolism: a simulation assessment using the "Advanced Dissolution, Absorption, Metabolism (ADAM)" model. Curr Drug Metab. 2010;11:716-29.

44. Shugarts S, Benet LZ. The role of transporters in the pharmacokinetics of orally administered drugs. Pharm Res. 2009;26:2039-54.

45. Moreira DS, Monte Neto RL, Andrade JM, Santi AM, Reis PG, Frezard F, Murta SM. Molecular characterization of the MRPA transporter and antimony uptake in four New World Leishmania spp. susceptible and resistant to antimony. Int J Parasitol Drugs Drug Resist. 2013;3:143-53.

46. Prieto P, Hoffmann S, Tirelli V, Tancredi F, Gonzalez I, Bermejo M, De Angelis I. An exploratory study of two Caco-2 cell models for oral absorption: a report on their within-laboratory and between-laboratory variability, and their predictive capacity. Altern Lab Anim. 2010;38:367-86.

47. van Breemen RB, Li Y. Caco-2 cell permeability assays to measure drug absorption. Expert Opin Drug Metab Toxicol. 2005;1:175-85.

48. Turco L, Catone T, Caloni F, Di Consiglio E, Testai E, Stammati A. Caco-2/TC7 cell line characterization for intestinal absorption: how reliable is this in vitro model for the prediction of the oral dose fraction absorbed in human? Toxicol In Vitro. 2011;25:13-20.

49. Hidalgo IJ. Assessing the absorption of new pharmaceuticals. Curr Top Med Chem. 2001;1:385-401.

50. Hanpitakpong W, Banmairuroi V, Kamanikom B, Choemung A, Na-Bangchang K. A high-performance liquid chromatographic method for determination of praziquantel in plasma. J Pharm Biomed Anal. 2004;36:871-6.

51. Gonzalez-Esquivel DF, Okuno CM, Sanchez Rodriguez M, Solelo Morales J, Cook HJ. Sensitive high-performance liquid chromatographic assay for praziquantel in plasma, urine and liver homogenates. J Chromatogr. 1993; 613:174-178.

52. Shah SR, Dey S, Pradhan P, Jain H, Upadhyay UM. Method development and validation for simulataneous estimation of albendazole and praziquantel in bulk and in a synthetic mixture. J Taibah Univ Sci. 2014;8:54-63.

53. Kulik A, Szczotkowska A, Bialecka W, Podolska M, Kwiatkowska-Puchniarz B, Mazurek A. Determination of active substances in binary mixture antiparasitic veterinary formulations by HPLC. Acta Pol Pharm. 2011;68: 467-72.

54. Havlikova L, Brabcova I, Satinsky D, Matysova L, Luskacova A, Osicka Z Solich P. Optimisation of an HPLC method for the simultaneous determination of pyrantel pamoate, praziquantel, fenbendazole, oxfendazole and butylhydroxyanisole using a phenyl stationary phase. Anal Methods. 2012;4:1592-7.

55. Simon GG. Impacts of neglected tropical disease on incidence and progression of HIV/AIDS, tuberculosis, and malaria: scientific links. Int J Infect Dis. 2016;42:54-7.

56. Remmel RP, Kawle SP, Weller D, Fletcher CV. Simultaneous HPLC assay for quantification of indinavir, nelfinavir, ritonavir, and saquinavir in human plasma. Clin Chem. 2000;46:73-81.

57. Ridtitid W, Wongnawa M, Mahatthanatrakul W, Punyo J, Sunbhanich M. LC determination of praziquantel in human plasma. J Pharm Biomed Anal. 2002;28:181-6.

58. Pontes FLD, Pontarolo R, Campos FR, Cleverson J, Gasparetto MAC, Piantavini MS, Badaró ACL. Development and validation of an HPLC-MS/MS method for simultaneous determination of ivermectin, febantel, praziquantel, pyrantel pamoate and related compounds in fixed dose combination for veterinary use. Asian J Pharm Clin Res. 2013;6:191-200.
59. Shah SR, Dey S, Pradhan P, Jain HK, Upadhyay UM. Method development and validation for simulataneous estimation of albendazole and praziquantel in bulk and in a synthetic mixture. Journal of Taibah University for Science. 2014; 8:54-63.

\section{Submit your next manuscript to BioMed Central and we will help you at every step:}

- We accept pre-submission inquiries

- Our selector tool helps you to find the most relevant journal

- We provide round the clock customer support

- Convenient online submission

- Thorough peer review

- Inclusion in PubMed and all major indexing services

- Maximum visibility for your research

Submit your manuscript at www.biomedcentral.com/submit

) Biomed Central 